\title{
Applying and advancing internalization theory: The multinational enterprise in the twenty-first century
}

\author{
Rajneesh Narula ${ }^{1}$, \\ Christian Geisler Asmussen ${ }^{2,3}$, \\ Tailan $\mathrm{Chi}^{4}$ and \\ Sumit Kumar Kundu ${ }^{5}$

\footnotetext{
${ }^{1}$ Henley Business School, University of Reading, Reading, UK; ${ }^{2}$ King's Business School, King's College London, Bush House, 30 Aldwych, London WC2B 4BG, UK; ${ }^{3}$ Copenhagen Business School, Frederiksberg, Denmark; ${ }^{4}$ Lubar School of Business, University of Wisconsin-Milwaukee, Milwaukee, USA; ${ }^{5}$ Florida International University, University Park, USA

Correspondence:

CG Asmussen, King's Business School, King's College London, Bush House, 30 Aldwych, London WC2B 4BG, UK.

Tel: +44 (0)20 7848 4389;

e-mail: christian.asmussen@kcl.ac.uk
}

\begin{abstract}
Internalization theory has provided a resilient analytical framework that explicitly or implicitly underlines much of International Business scholarship. Internalization theory is not a monolithic body of knowledge; instead, it has devolved into several 'streams', each of which focuses on the interests of particular epistemic communities, while also acting as a more generic organizing framework for those more broadly interested in its application to real-world challenges. Following a review of the various streams, we trace the frontiers of current research of the broader internalization framework and identify emerging themes raised by the papers in the special issue. These include transaction cost considerations in the bundling and recombination of assets across diverse contexts, the growing relevance of quasi-internalization, the theoretical challenges of (bounded) rationality for internalization theory, and the increasing disconnect between ownership, control and responsibility. These developments point to new research frontiers for scholars looking to apply or advance internalization theory.
\end{abstract}

Journal of International Business Studies (2019) 50, |23|-|252.

https://doi.org/10.1057/s4 I267-019-00260-6

Keywords: internalization theory; resource-based view; transaction cost economics; cognitive psychology

\section{INTRODUCTION}

It is no exaggeration to say that, over the last 50 years, internalization theory has become a generally accepted theory of the Multinational Enterprise (MNE). Providing an analytical framework that has explicitly or implicitly underlined much of the progress in International Business (IB) research, internalization theory allows the prediction of a great number of organizational regularities in IB. These range from entry mode choices to internal organizational design in terms of structural and strategic governance, as well as the structuring of their interface with external economic actors. By and large, it has weathered a variety of criticisms, adapting to the various new debates that have emerged about its continued applicability in a rapidly changing world. Socio-economic and political realities are ever-more fluid today, as the nature of the global economy continues to evolve and as novel types of cross-
Received: 21 March 2019

Revised: 18 May 2019

Accepted: 22 July 2019

Online publication date: 26 August 2019 
border transactions and forms of MNEs have arisen, raising new questions about the internalization theory's applicability.

This special issue on Applying and Advancing Internalization Theory addresses some of the most current lacunae. This introductory paper draws together and synthesizes the lessons learnt from the various papers in this special issue, while also highlighting the contemporary and contentious issues for future research. We do so by first outlining how the various 'streams' of internalization theory have emerged starting from the late 1970s. Internalization theory is a large canvas; the various streams focus on the interests of particular epistemic communities, while also acting as a more generic organizing framework for those more broadly interested in IB to specific circumstances. We then build a stylized framework of modal choice outcomes drawing together these streams, and use this framework to identify the principal themes that capture the key insights and contributions of the papers in the special issue. Finally, we discuss potential avenues for future research and conclude.

\section{INTERNALIZATION THEORY AS AN EPHEMERAL FRAMEWORK: SOME ANTECEDENTS}

For the non-specialist (by which we mean those whose primary interest is in applying internalization theory as an organizing framework, rather than developing specific aspects of it), differentiating between the alternative approaches (e.g., 'internalization theory' vs. 'eclectic paradigm' vs. 'new internalization theory') can be bewildering. These approaches seem to overlap, but yet, as those devoted to a particular approach will tell you, they are distinct. The overlap of the various 'streams' is no coincidence, with the progenitors of each actively engaging with one another during the latter part of the 1970s (the term 'Reading School' is sometimes used to refer to them collectively, due to the overlapping physical colocation of key authors during this era). Yet, each 'stream' has evolved and been adapted to serve particular purposes, reflecting to an extent the interests of the core scholars, and those of successive generations of researchers who have engaged with conceptual issues. Our contention in this paper (and special issue) is that, despite various 'quarrels' over minutiae, there is much more in common than differentiates the various streams. Most importantly, they share a common set of principles and epistemology, and bind the field of IB together.

Practically speaking, IB has remained interdisciplinary and phenomenon-driven. This has created a pragmatic playing field, with scholars seeking to explain salient real-world phenomena (most recently, for instance, the rise of the global value chain, or digital technologies) drawing from sister disciplines of social sciences and trying to integrate significant observations from the actions of MNEs with the core pillars of internalization theory (broadly defined). Internalization theory has been fairly flexible in absorbing useful complementary concepts, and, to this extent, it is less of a theory, but more of a paradigm. For instance, institutional theory now cohabits with internalization, as does, increasingly, behavioral economics. Scholars interested in corporate social responsibility or international human resource management (to name just two) have sought to create bridges to labor economics, sociology, cognitive and social psychology, and moral philosophy. Internalization theory has been forgiving to the practical needs of those who modularize and cross-breed its components in order to create the tools to explain, optimize or predict the actions of MNEs, or the actors that they engage with.

\section{The Buckley and Casson Stream}

Buckley and Casson (1976) explained why the MNE prefers to organize cross-border value-adding activities through the hierarchy rather than the market. It holds to the economics approach that the market mechanism represents a default option under ideal conditions, and, where the market is inefficient, the MNE can internalize transactions through its internal hierarchy. Buckley and Casson argued that markets for intermediate products in cross-border contexts have a variety of structural imperfections that significantly escalate transaction costs. The existence of the MNE can be explained by its superior efficiencies (to arm's-length market transactions) in the cross-border exchanges of intermediate products. Transaction costs in the intermediate products markets are usually very high because the risk and uncertainty of both buyers and sellers are reflected in the transactions. Specifically, the transactions of intermediate products such as technology and know-how often involve substantial costs in negotiation, monitoring, and enforcement. For intangible assets, 'information asymmetry' between buyers and sellers inevitably occurs. High transaction costs are not 
just limited to intangible assets. Where inputs or intermediate goods are scarce or locationally bound, transaction costs may also cause market failure.

More recent work of Buckley and Casson with coauthors have since expanded the scope of analysis to international joint ventures (e.g., Buckley \& Casson, 1998a, b), location choice in a firm's global production network (e.g., Buckley \& Hashai, 2002; Casson \& Wadeson, 2012), and firm-specific advantages (FSAs) and internal control mechanisms (e.g., Buckley \& Casson, 1998a), while maintaining a certain consistency with their original model and its underlying assumptions.

\section{The Hennart Stream}

Hennart $(1977,1982)$, in parallel to Buckley and Casson (1976), contributed to the theory of the MNE by considering additional types of transaction costs, such as measurement and enforcement costs arising from bounded rationality and opportunistic behavior in markets. In a comprehensive application of transaction cost thinking to the global context, Hennart (1989) argued that MNEs arise to organize interdependencies across borders in scenarios where markets fail to do so, describing failures in markets for knowledge, reputation, intermediate products, distribution, and financial capital. An important contribution to this thinking was Hennart's (1993) conceptualization of the 'swollen middle' between market and hierarchy. In particular, he made a distinction between governance forms (markets and firms) and the coordination mechanisms that they (predominantly) use (behavioral and price controls), proposing a continuum of hybrid forms whereby firms deploy price-based coordination mechanisms internally or behavioral constraints to govern inter-firm relationships. As this special issue demonstrates, the latter part of this observation, in particular, has become increasingly pertinent with the rise of global value chains.

Furthermore, Hennart's (1988, 2009) work also shifts the focus of the analysis from the deployment of the MNE's own assets overseas to the bundling of complementary assets across borders as well as the tradeoff in the choice of alternative organizational forms for joint use of such assets. This stream of work also highlights the roles of two other salient transaction cost problems in the choice of asset-bundling modes, namely, moral hazard in the trading of tacit knowledge, and holdup in the joint use of assets that require mutual adaptation or co-specialization (Teece, 1986; Hennart, 1988; Chi, 1994).

More recent work by Hennart and his co-authors has examined the international expansion of small family firms (Hennart, Majocchi \& Forlani, 2017) and the conditions for firms to emerge and survive as 'born globals' (Hennart, 2014), further developing the asset bundling perspective (Hennart, 2012). This body of research suggests that the adoption of a business model requiring little local adaptation in product and marketing-mix makes access to complementary local expertise inconsequential and thus enables these firms to expand overseas using primarily the 'market' mode.

\section{The Rugman Stream}

Following Rugman's initial contribution (1981) that relied heavily on the transaction cost economics (TCE) approach favored by the Buckley and Casson, and Hennart streams, the Rugman stream gradually expanded internalization theory by building into it explicit considerations of resource characteristics, in parallel to developments in strategy that led to the resource-based view (RBV) (e.g., Wernerfelt, 1984; Barney, 1991). Like many of his strategy contemporaries, Rugman was much influenced by the work of Penrose (1959), and took a more firm-specific view, which has been especially influential in addressing strategic management issues. Like Dunning, he considered proprietary assets to be a sine qua non for the MNE, labeling them FSAs (both drawing from Hymer, 1960). In much the same way as does the eclectic paradigm, Rugman's version of internalization theory uses the large MNE as its unit of analysis, since it represents the most complex governance case. Hence, it involves a variety of inter-firm transactions between the MNE and its business and non-business stakeholders, and takes as a given that there are also numerous intra-MNE transactions (Narula \& Verbeke, 2015). The key interactions of the MNE with these stakeholders, and the degree to which it internalizes activities, are explicitly acknowledged through attention paid to country-specific advantages (CSAs) and the value creation and transaction cost implications of the cross-border interactions.

The Rugman School (in collaboration with a number of others, but especially Verbeke) inspired others to deepen the linkages with RBV (Chi, 1994). An important development in this regard was the focus on the geographic 'reach' or fungibility of FSAs, making the critical distinction between 
location-bound and non-location-bound FSAs (Rugman \& Verbeke, 1992, 2003, 2004). This is an example of a discussion that has also been touched upon in the 'core' RBV literature (in the form of factor specificity, see, e.g., Montgomery \& Wernerfelt, 1988). However, in the context of internalization theory, RBV has taken on an entirely different and much more central position, due to the importance of distance in IB (Pitelis \& Verbeke, 2007).

The Penrose-inspired approach was crucial to the analysis of how MNEs function internally. This has seen the application of the Rugman stream to a variety of management-oriented subjects, including headquarters-subsidiary interactions, and subsidiary specific advantages (SSAs) in the MNE (Rugman \& Verbeke, 2001; Asmussen, Pedersen \& Dhanaraj, 2009), and-perhaps most importantlythe prevalence of regional rather than global strategies by MNEs as a means to capture value from their FSAs (Rugman \& Verbeke, 2004; Rugman, 2005; Asmussen, 2009; Rugman, Verbeke \& Yuan, 2011).

The later extensions of this stream of internalization theory adapted newer and more refined concepts from RBV-inspired research, emphasizing the focus on the MNE, its strategy, and its actions. By analyzing a broad range of organizational modes for the exploitation of FSAs, this stream has shown that the basic framework of internalization theory is applicable to explaining not only the raison d'être of the MNE but also the choice between the relevant organizational modes in IB (Chi, 2015).

\section{The Dunning Stream}

The eclectic paradigm, originally developed by John Dunning (also referred to as the OLI paradigm) in its basic conception (Dunning 1977, 1993, 2000; Cantwell \& Narula, 2001; Dunning \& Lundan, 2009; Eden \& Dai, 2010; Narula, 2010, 2012), can be described as consisting of three elements: ownership advantages, location advantages, and internalization advantages. Proprietary assets of firms (particularly intangible assets or capabilities that are not location-bound) are referred to as 'ownership-specific advantages' (O) that afford their owners rent-generating ability and competitive advantages. They are synonymous with FSAs. ${ }^{1}$ The greater the ownership advantages of the investing firms, relative to those of other firms, the more likely will the MNE be able to engage in foreign activities.
The choice of location matters within the eclectic paradigm. Location-bound assets associated with particular geographies (countries, regions or cities) from which the MNE can benefit via combination with their ownership advantages are referred as 'location-specific advantages' (L). They are synonymous with CSAs. When immobile location-bound endowments or resources to which the firm desires access (for cost or quality reasons) reside in a foreign (rather than a domestic) location, the firms will likely choose to locate activities in that host location. Where firms have $\mathrm{O}$ advantages that they seek to utilize in conjunction with L advantages of the host location, they must decide whether it is in their interest to internalize these foreign activities, and to what extent to do so. The strength of such 'internalization advantages' determines the mode of foreign operations, and how intra-firm interdependencies within the MNE will be organized.

Like the Rugman stream, this stream also merges Penrose's (1959) theory of firm growth with Coase's (1960) transaction cost theory on the choice of organizational form, but it also draws from neoclassical trade theory to shed light on the MNE's choice of investment location (Narula, 2012).

\section{Internalization: Holistic Theory or Modular Toolkit?}

To summarize the preceding discussion, internalization theory arguably spans several distinct but individually influential schools of thought, while appealing to scholars for very different purposes. Roughly speaking, one community of scholars is more 'specialist' and considers internalization theory to be a 'theory' in the strict sense of the word, a view shared by the Buckley and Casson and Hennart streams, with clear underlying assumptions that allow for a specific set of propositions affording parsimony (see Buckley \& Casson, 2019 for a lucid discussion). A second scholarly community (admittedly rarely identified as such) is more 'generalist' and sees internalization theory as a modular toolkit that provides the basis for a general IB framework to understand all aspects of socio-economic behavior that impinge on the MNE. Largely speaking, this second view is the ascendant one, utilizing key concepts from internalization theory in conjunction with theories from other related fields. The specialists generally take umbrage at the selective use of key concepts in novel circumstances: Dunning's view of the eclectic paradigm was that the three aspects of the OLI model needed to be considered together, a view shared by Cantwell 
(2015), while Narula (2010) argued that, for the user, it is a toolkit which it has retained its popularity precisely because it is amenable to modular use.

Certainly, the key concepts of ownership advantages/FSAs and location advantages/CSAs have entered into the IB lexicon and found universal application across a variety of adjoining disciplines. From an economics perspective, subject areas such as innovation studies, development studies, trade economics, and economic geography apply these ideas. Among management scholars, HRM, ethics, and innovation management are areas where the internalization framework helps to integrate communities of practice. However, there is a danger that, in attempting to establish the framework as a 'big tent' or 'envelope', while providing us with the basis to understand many things, it will require large and ever-growing lists of categories and subcategories, sub-paradigms and extensions, because these lists have the potential to be interminably long if they are exhaustive, and therefore ultimately tautological (Narula, 2010).

\section{INTERNALIZATION: AN ORGANIZING FRAMEWORK}

Drawing together the various streams of internalization theory, we now sketch a stylized account of international governance mode choice that serves as an organizing framework for how to understand the papers in this special issue.

\section{Internalization, FSA Recombination, and Market Imperfections}

Market imperfections/failure ${ }^{2}$ is a basic premise in all streams of internalization theory. It plays a particularly central role in the Buckley and Casson stream and Hennart stream, and lies in the initial theorizing by both Dunning and Rugman (see also Dunning \& Rugman, 1985). The Rugman stream has further built on this by integrating it with considerations of FSA management. Rugman \& Verbeke (2003) emphasize economies of scope specifically between non-location-bound FSAs (e.g., technological knowledge originating in one country) and location-bound assets (e.g., distribution channels and market knowledge in another). While it would be possible for a firm owning nonlocation-bound assets to sell access to (i.e., license) these assets to a partner firm in the host country with location-bound assets (or vice versa), market imperfections may lead the MNE to internalize these assets. Internalization can facilitate the valueenhancing recombination of the assets (Pitelis \& Verbeke, 2007), a process that is enhanced by the specialized internal routines and capabilities of the MNE hierarchy.

The concept of FSA recombination has gained greater attention in IB research, examining how MNEs can access complementary resources in foreign markets by using the market for the resources themselves, the market for the services of those resources, or the market for the firms owning them (Hennart, 2009; Verbeke, 2013; Collinson \& Narula, 2014). This idea has formed the basis for linking internalization theory explicitly with dynamic capabilities, and has led to an increasing acknowledgement of the importance of entrepreneurial action and resource recombination inside the MNE (Narula \& Verbeke, 2015). Indeed, Verbeke (2013) and Narula (2014) argue that the capability to recombine is a source of firm-specific advantage in its own right. The capability to recombine is firm-specific and tacit, not easily acquired or transferred. MNEs require efficient internal markets and well-structured cross-border hierarchies (otherwise, there are limited economies of common governance), and recombination of FSAs are especially significant for successful MNEs to act as 'meta-integrators' that combine knowledge resident within the various constituent units within the firm and extract an advantage from it (Narula, 2017; Madhok, 2015).

Of course, an important question pertains to the source of market failure: i.e., why can different asset types not be recombined as efficiently through the market, for example, with one firm licensing its knowledge across borders to the other? The different streams of internalization theory emphasize different transaction cost problems as the answer to this question. Specifically, the analysis of Buckley and Casson (1976) highlights adverse selection and rent misappropriation in the trading of proprietary knowledge. Hennart $(1989,2009)$ highlights moral hazard in the trading of tacit knowledge and holdup in the joint use of assets that require mutual adaptation or co-specialization. It should be noted that the exchange of knowledge, explicit or tacit, necessarily entails mutual adaptation. Specifically, the recombination of complementary knowledge from two different parties can be achieved through (1) a transfer of one party's knowledge to the other or (2) a joint provision of their respective knowledge to the recombination process. Both knowledge transfer (involving teaching and learning) and 
the joint provision are forms of mutual adaptation. Lack of full cooperation by either party, because of misaligned incentives or misallocated control rights, can give rise to one of the transaction cost problems ex post in the form of cheating (i.e., rent misappropriation), shirking (i.e., moral hazard) or power jockeying (i.e., holdup). As Pitelis and Verbeke (2007) point out, 'melding' non- locationbound and location-bound assets across diverse and distant contexts is likely to require substantial efforts of mutual adaptation, which may not be forthcoming if the two parties are not properly incentivized.

The transaction cost problems associated with the MNE's FSAs are well understood, since they have been the focus of study in internalization theory from the beginning, for example, with market failures applying to the licensing of the MNE's tacit non-location-bound knowledge. Less well scrutinized are those associated with the local firm's FSAs that are complementary to the MNE's. Such location-bound FSAs often take the forms of manufacturing, marketing and management expertise that is highly tacit and specific to the culture and institutions of the host country. In a discussion of knowledge transfers between U.S. firms and their Japanese partners, Hamel, Doz \& Prahalad (1989) argued that the Japanese firms' knowledge in manufacturing tended to be mostly tacit and culturally-embedded, and thus more difficult for their U.S. partners to learn via an alliance. More recently, other East Asian manufacturers have developed highly competitive operations that take advantage of the culturally- and institutionallyembedded human resources in China and neighboring countries. The Taiwanese-owned Apple contractor, Foxconn, for instance, achieves both high quality and low cost as well as an extremely fast changeover time; its manufacturing facilities have up to 300,000 employees mostly living in company-run residences fitted with a full range of services, including medical clinics and entertainment venues (Duhigg \& Bradsher, 2012). Efficient operations of these facilities entail orchestrating a complex set of bundles of tacit knowledge in manufacturing, logistics, human resource management, and government relationships. Arm's-length contracting is likely to suffer both moral hazard and holdup problems because the complex operations are hard for an outsider to monitor, and because the OEM manufacturer must make substantial investments specific to the MNE client's operations. Another type of location-bound FSAs that can also engender high transaction costs are local distribution networks and marketing skills. As Hennart $(1988,2009)$ explains, independent distributors may 'refuse to make optimal amounts of investments' in marketing, distribution, and service that are specific to an MNE's products, out of a fear of being held-up after the investments are made. In short, moral hazard and holdup are like the most salient transaction cost problems affecting requisite access to such location-bound FSAs.

Hence, difficulty in aligning incentives and control rights via an arm's length deal in mutual adaptation and FSA recombination gives rise to internalization advantages. Which of the two firms can better serve as an integrator in combining their FSAs? Economic models of property rights suggest that the answer depends not only on the relative contributions of their respective efforts or investments to value creation but also on the relative levels of transaction costs that their respective efforts or investments engender (Grossman \& Hart, 1986; Chi, 1996). Furthermore, there exist mechanisms that allow cash flow rights (embedded in ownership shares) and control rights to diverge in such hybrid forms of organizations as joint ventures and alliances, particularly the use of personnel assignments to designate specific decision rights to only one partner or to 'wall off' sensitive information from the other (Chi \& Roehl, 1997; Chi \& Zhao, 2014; Roehl \& Truitt, 1987).

When there are substantial market transaction costs associated with the melding of non-locationbound and location-bound FSAs, the MNE may arise as a vehicle to mitigate those costs. There are a number of reasons why internalization within the MNE can alleviate the market imperfections described above. First, internalization enables the corporate HQ to engage actively in the selection and training of managers, such that the goals of these managers align better with those of the firm in its entirety (Ouchi, 1979), including what scholars have termed 'socialization', e.g., through rotation of personnel across dispersed units (Edström \& Galbraith, 1977; Chi \& Nystrom, 1998; Zeng, Grøgaard \& Steel 2018, Ambos, Kunisch, Leicht-Deobald \& Steinberg, 2019). Second, internalization facilitates monitoring, since it can be imposed by HQ using fiat without risking the appropriation of firm-specific knowledge by potential competitors. Third, and related to the second point, to make sure that sufficient effort is invested in FSA recombination, $\mathrm{HQ}$ can use subjective evaluations linked to firing, bonus or promotion 
decisions (Baker, Gibbons \& Murphy, 1994; Klein \& Murphy, 1997). Fourth, internalization enables the HQ to weaken potential perverse incentives by removing residual claimancy from the manager of each unit, and thereby also lowering the gains from free-riding (Harris \& Raviv, 1979).

Of course, MNEs-which are essentially internal markets-are also liable for their own internal organization costs. Hierarchical organization comes with its own types of transaction costs, sometimes termed 'hierarchical costs' (Hennart, 1993) or what Buckley \& Casson (1976) refer to as 'communication costs.' Based on the transaction cost-economizing logic, the MNE will only arise if these hierarchical costs are lower than the costs of market imperfections. However, even if the MNE's internal markets ceteris paribus are more efficient than markets, this does not mean that firms are always more efficient. First, the more complex the MNE organizationally, and the more intricate and the larger the engagement with external actors, the less efficient the MNE is likely to become (Narula, 2014). The meta-integration role of headquarters can become more cumbersome, causing internal coordination costs to rise, perhaps exponentially, as the MNE expands in scale and scope. Potentially, both the costs of the market and the costs of the hierarchy may be higher than the benefits of the cross-border transaction in the first place, in which case no exchange will take place (Hennart, 1993). If these transaction costs increase with diversity and distance (broadly defined), that implies a natural upper limit to the geographic scope of the MNE (Goerzen \& Beamish, 2003).

Finally, it remains important from a practical perspective to acknowledge the geographic locus of market imperfections. The host country market imperfections described above may be particularly difficult to address, because the traditional property rights solution-assigning ownership rights and integrator functions-might imply the host country firm acquiring the MNE. Such an acquisition, however, may be prohibitively costly if the local firm does not have financial capital and managerial resources, including the capacity for efficiently managing the MNE's assets that may be either highly specialized or highly diversified across multiple industries and countries. At the same time, the MNE may have substantial difficulty in internalizing the location-bound FSAs (e.g., Apple and Foxconn's manufacturing assets in China) in the host country due to its lack of the requisite cultural and institutional background for integrating those FSAs.

\section{Transaction Type FSAs and the Tradeoff Between Internalization and Quasi-Internalization}

Early internalization theory-based analyses involved a comparison of market transaction costs with the cost of the MNE hierarchy. However, several complications quickly arise as to the practical implications of such an approach. First, the hierarchical costs described above are not exogenous, but rather endogenous, to experience, managerial skills, and routines. Rugman \& Verbeke (1992) noted that firms vary in their capabilities to manage interdependencies within their corporate networks. The intangible skills of effectively designing, adapting, and managing complex hierarchies are not easily acquired, and need to be developed through experience. Nascent MNEs (such as emerging economy MNEs) tend not to have the depth of knowledge to achieve economies of common governance, or effectively transfer FSAs to and from different locations (Cuervo-Cazurra, 2012; Narula, 2012, 2017). The more complex the MNE structure, the more important these skills (Birkinshaw \& Pedersen, 2001), which have been termed transaction-type FSAs and denoted $O_{T}$ (Dunning, 1993; Narula, 2014, 2017). Indeed, there is a constant push-pull between the opposing forces promoting centralization and autonomy within the MNE (Young \& Tavares, 2004).

However, we argue that $O_{T}$ capabilities can be specialized, not only towards internalization but also towards externalization in the form of relationship-based contracting rather than arm'slength dealings. Such externalization is often characterized as quasi-internalization, since it relies neither on spot market transactions nor on one firm taking over the other by equity ownership (Mowery, Oxley \& Silverman, 1996; Hamel, 1991; Dunning, 1995; Cantwell \& Narula, 2001). In quasiinternalization, the parties involved are independently owned firms, which nevertheless facilitate mutual adaptation by utilizing not only price incentives and behavioral constraints (Hennart, 1993) but also additional mechanisms such as reputation effects (the 'shadow of the future') and social ties to mitigate transaction costs. Quasiinternalization also has a significant strategic motivation, which can outweigh cost-economizing motivations (Hagedoorn, 1993, Narula \& Hagedoorn, 1999). 
The MNE needs specialized skills to scan its boundaries in order to assess the resources available within its network of external partners (and more broadly within the market), and to manage these relationships. The development of $O_{T}$ capabilities specifically to manage external transactions is an important reason for the increasing conceptual separation of ownership and control. For example, to organize mutual adaptation between independent firms in different countries, managers might accumulate 'hard' capabilities in contract design and enforcement as well as 'soft' capabilities in establishing trust and inter-personal relationships between firms (Cullen, Johnson, \& Sakano, 2000). This relates to the concept of 'partnering capabilities' (Schilke \& Goerzen, 2010; Dhanaraj \& Parkhe, 2006), which have been linked to MNEs' ability to cross geographic and cultural boundaries (Asmussen \& Goerzen, 2013). The ability to build inter-firm relationships facilitates cross-border FSA recombination, since each firm will be comfortable investing in relationship-specific FSA adaptation without fearing that their partners will take advantage of them, thereby achieving some of the benefits of internalization, but without the hierarchical costs. This, in turn, can enable firms to build successful reputation-based relationships throughout the value chain, as described by Gereffi, Humphrey and Sturgeon (2005). Nonetheless, MNE-dominated global value chains (GVCs) remain prone to coordination failures and face a higher risk of shirking than vertically integrated supply chains. Likewise, alliances are known to suffer from a high failure rate (Reuer \& Zollo, 2005; White \& Siu-Yun Lui, 2005; Wang, Dou, Zhu, \& Zhou, 2015). This suggests that there are also costs associated with quasi-internalization.

Reflecting the distinction between different transactional FSAs, we denote the internal organizational capabilities, $O_{T I}$, and the external relationship ones, $O_{T E}$. Technological advances may contribute to making both types of FSAs more salient than they were a decade ago, for example by reducing communication costs. Furthermore, capabilities for 'modularization' can allow MNEs to reduce the need for coordination between value chain activities, thereby lowering coordination costs irrespective of whether internal or external governance is employed (Asmussen, Larsen \& Pedersen, 2016). At the same time, $O_{T I}$ and $O_{T E}$ are distinct capabilities in the sense that they rely on different skillsets and mechanisms (in particular, $O_{T I}$ can make use of fiat while $O_{T E}$ cannot), and firms may specialize in either direction. Importantly, diversity in $O_{T I}$ and $O_{T E}$ capabilities implies that the optimal choice of governance modes is contingent on the nature and level of a firm's organizational capabilities. In addition, since $O_{T E}$ enables the firm to attain control without corresponding ownership, ownership and control can become less synchronized, perhaps increasingly so, underscoring the importance of the 'swollen middle' (Hennart, 1993).

Figure 1 illustrates how the optimal choice of governance mode depends not only on the severity of market imperfections for the FSAs to be recombined but also on the MNE's organizational capabilities. Here, we consider not only imperfections in the market for the services of the assets underlying each firm's FSAs but also imperfections in the market for the assets per se and for the control of the firm owning the assets. The level of market imperfections varies not only with the institutional characteristics of the market (e.g., contract laws and intellectual property laws) but also with the attributes of the services or assets being traded (e.g., codified vs. tacit knowledge) and the absorptive capacity of the firm trying to access the other's FSAs (i.e., the ability to evaluate, digest, and manage the assets underlying the FSAs; see Cohen \& Levinthal, 1990).

We distinguish three levels of market imperfections:

- Low: Contracting for the services of the assets (e.g., via a licensing or technical assistance agreement) does not engender significant transaction cost problems.

- Intermediate: Transaction cost problems with trading in the services of the assets are significant but not too severe to render the mechanisms of quasi-internalization ineffectual. In addition, the market for the underlying assets or the firm owning the assets is functional so long as the acquirer has sufficiently strong absorptive capacity.

- High: Transaction costs problems with trading in the services of the assets are too severe for the mechanisms of quasi-internalization to remedy. Furthermore, the market for the assets per se and the market for the control of the firm owning the assets also suffer from high transaction costs. This condition can be characterized as triple market failure. 


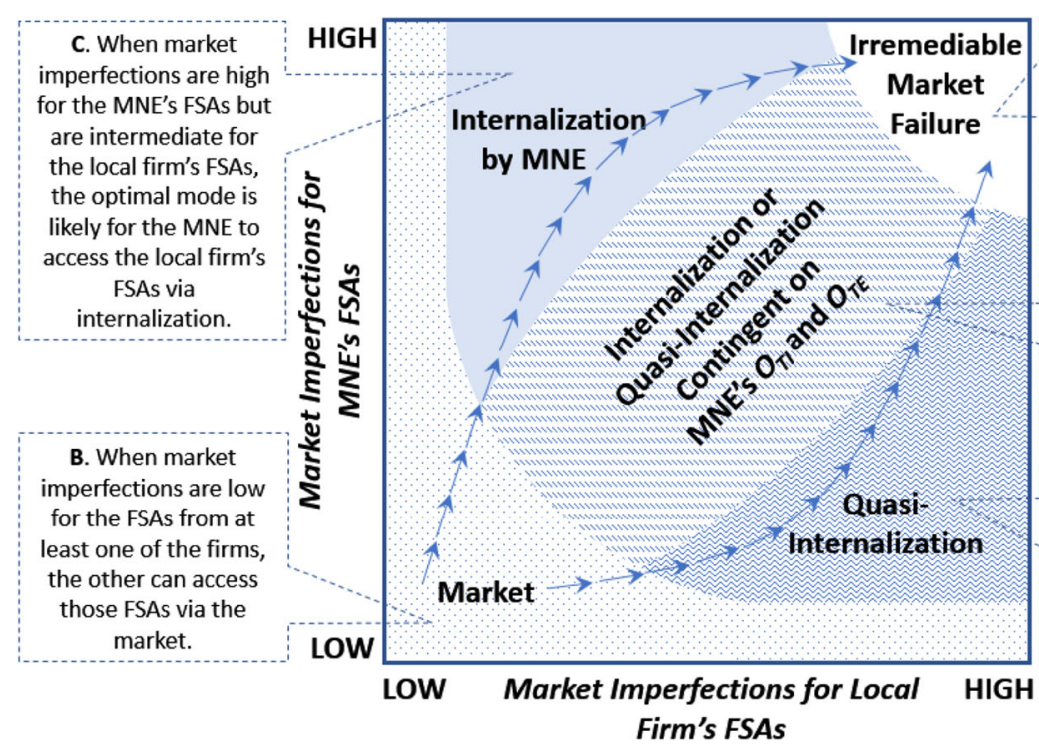

A. When market imperfections are high for the FSAs of both firms, market failure may become irremediable in the sense that transaction costs totally dissipate the gain from mutual adaptation between the FSAs. This condition arises when it is economically infeasible for either firm to purchase the services of the assets underlying the other firm's FSAs or acquire the assets pe se or the entire firm as a going concern.

E. When market imperfections are intermediate for both sets of FSAs, the optimal mode could be for the MNE to access the local firm's FSAs via either internalization or quasiinternalization, contingent upon its organizational capabilities $O_{T I}$ and $O_{T E}$.

D. When market imperfections are high for the local firm's FSAs but are intermediate for the MNE's FSAs, the optimal mode is likely for the two firms to recombine their FSAs via quasi-internalization under the assumption that it is not economically feasible for the local firm to acquire the assets underlying the MNE's FSAs.

Figure 1 Contingency of governance mode choice on transaction-type capabilities.

Depending on whether significant transaction cost problems plague the FSAs of only one or both of the firms, the market failure may be single-sided or double-sided. Since our analysis of FSA recombination here takes an MNE-centric view, we assume away the possibility that a local firm is able to internalize the MNE's FSAs by acquiring the underlying assets or the entire firm as a going concern (due to the relative financial capitalization, specialization, and/or diversification of the MNE). When the internalization option is infeasible, the two firms will have to rely on quasi-internalization to remedy market imperfections for their FSAs. The following comments refer to Figure 1 :

A. When the severity of market imperfections is high for the FSAs of both firms, transaction costs may become so high as to totally dissipate the potential gains from mutual adaptation between the FSAs. This is shown by the unshaded zone in the top-right corner of the figure, representing the case of double-sided triple market failure whereby the markets for the services of each firm's assets, the assets themselves, and the firm owning the assets all suffer from irremediable failure. In other words, it is not economically feasible for either firm to purchase the services of the assets underlying the other firm's FSAs or to acquire the assets per se or the entire firm as a going concern.

B. When market imperfections for the FSAs from at least one of two firms are low, the other can access those FSAs via the market without incurring significant transaction costs. In particular, when the market for the services of the assets is functional, arm's-length contracting (e.g., licensing or technical assistance) presumably becomes the preferred approach, since it is less expensive than carving the assets out of the firm or taking it over as a going concern. This is shown by the dotted zone along the horizontal and vertical axes.

C. When market imperfections are high for the MNE's FSAs but intermediate for the local firm's FSAs, the optimal mode is likely for the MNE to access the local firms FSAs via internalization, drawing on its $O_{T I}$ capabilities. In this case, arm's-length contracting is ruled out by the presence of significant transaction costs for trading in the services of the local firm's assets, but the market for the local firm itself is sufficiently functional for it to be absorbed within the MNE. This is shown by the solidshaded zone at the top.

D. When market imperfections are high for the local firm's FSAs but intermediate for the MNE's FSAs, the optimal mode is likely for the two firms to recombine their FSAs via quasi-internalization, drawing on their $O_{T E}$ capabilities. In this case, not only is it economically infeasible for the local firm to acquire the assets underlying the MNE's FSAs as per our assumption stated above but significant imperfections in the market for the local firm's assets also make internalization by the MNE inefficient. This leaves 
the two firms with only the mechanisms of quasi-internalization as feasible remedies for the market imperfections, as shown by the pattern-shaded zone on the right.

E. When market imperfections are intermediate for both sets of FSAs, the optimal mode could be for the MNE to access the local firm's FSAs via either internalization or quasi-internalization, contingent on $O_{T I}$ and $O_{T E}$. In other words, the boundary between internalization and quasiinternalization may shift depending on the MNE's relative transactional capabilities. This is shown by the pattern-shaded zone in the middle.

The traditional focus of internalization theory is on the left-hand side of the figure, examining how market imperfections for the MNE's FSAs affect its choice of internalization versus the market. Further extensions of the theory recognize that the MNE's expansion can often benefit from recombining its FSAs with typically location-bound FSAs that reside in the host country and may also engender significant transaction costs. ${ }^{3}$ Our exposition summarized in Figure 1 recognizes not only the role of market imperfections for the two sets of FSAs to be recombined but also the role of the MNE's organizational capabilities in the choice of governance mode.

\section{Bounded Rationality and Efficiency Explanations of the MNE}

Figure 1 (and the extant theories on which it is based) implicitly builds on an assumption that efficient outcomes will prevail. This, in turn, relates to assumptions about rationality. Here, it is important to distinguish between the assumption of bounded rationality that underpins explanations of market failure, and the efficiency-based logic that leads from market failure to internalization. We will elaborate on each of these in turn.

On the one hand, internalization theory in its original version(s) explicitly built upon Simon's (1955) concept of bounded rationality. In a boundedly rational world, actors acquire information through past actions and experiences, and this creates boundaries to their knowledge set, thereby constraining and shaping their future transactions. A critical implication of this is the related (ever-present) risk of opportunism, referring to the human characteristic of self-interest, and the tendency to engage in transactions by choosing to disclose partial information in order to bias a transaction to one's own benefit. It plays a key part in internalization theory as firms seek to minimize the risks associated with opportunism, both within firms and between unaffiliated actors. Bounded rationality constrains the ability to write complete contracts and prevents actors from identifying (and avoiding) opportunistic behavior.

On the other hand, internalization theory shares with transaction cost economics a clear efficiencybased or economizing logic (Williamson, 1991). Since 'rational agents will internalize markets when the expected benefits exceed the expected costs' (Buckley \& Casson, 2009: 1567), it is expected that, in the long term, observed outcomes will gravitate towards governance structures that are consistent with the economic logic of internalization theory. This, of course, does not imply that mistakes are not made or that personal biases do not exist, but merely that such deviations will tend to drop out of IB scholars' samples (competed away by more efficient governance structures) or end up as error terms in their regression equations. However, as this special issue demonstrates, relaxing this assumption in specific and operational ways is likely to lead to new insights into internalization outcomes.

Bounded rationality also plays a key role in the discussion of the nature of 'advantages'. The proprietary assets of the firm are commonly described as firm-specific or ownership-specific 'advantages' relative to what might be available to other firms. The concept of 'advantage' is a reflection of the path dependency of internalization theory and its provenance as an extension of trade theory (e.g., comparative advantage). The use of the term 'advantage' can be misleading, because determining an advantage insinuates a 'comparative' aspect that implicitly draws from the assumption that actors are rational. Measuring the quality and value of proprietary knowledge, and its relative superiority to those of other firms, runs into the problem of the tacit nature of knowledge. It is challenging enough to determine ex ante the value of a firm's own assets; it is even more difficult to determine its value relative to the proprietary assets of one's competitors. The complexity is far greater for $O_{T}$ FSAs where knowledge is embedded in routines and institutions. This challenge extends to locationspecific advantages and CSAs (Narula, 2012; Narula \& Santangelo, 2012), and therefore, by extension, to internalization advantages. Actors sometimes have a self-interest in exaggerating the superiority 
of their proprietary resources, and, in other cases, such exaggeration may simply reflect their own biases and cognitive limitations. In other words, MNE managers may not know, even approximately, in which part of Figure 1 they are operating. To put this in an economics context: cognitive limitations can impede the maximization of the utility function even if the utility function includes non-financial objectives such as social or political ones in the case of state-owned enterprises (SOEs). Research in behavioral economics and cognitive and social psychology reveals that decision-makers may also be liable to systematic errors and biases that hinder the maximization of their utility function. An attempt to incorporate such errors and biases into the bounded rationality concept was made by Foss and Weber (2016a). The ensuing debate between Lumineau and Verbeke (2016) and Foss and Weber (2016b) on the role of bounded rationality relative to the role of opportunism in TCE theorizing points to the importance of further research not only on different forms of bounded rationality but also on different forms of opportunism.

Finally, bounded rationality also relates to the much-debated issue of trust-which in turn has strong managerial relevance for the development of especially $O_{T E}$ capabilities. Since such capabilities help MNEs establish inter-firm collaboration in their GVCs, and collaboration is dependent on trust (Das \& Teng, 2001), it follows that an important part of those capabilities might be the ability to build trust (Cullen, Johnson, \& Sakano, 2000). However, is trust rational, or does it require us to make different behavioral assumptions that might not hold in a given business setting? A rational understanding of trust emerges from game theory, where profit-maximizing firms will collaborate out of self-interest because they are interested in preserving the relationship. Hence, closely related to the reputation-based argument of Gereffi et al. (2005), opportunistic behavior in a GVC can be mitigated by the 'shadow of the future' (Baker, Gibbons \& Murphy, 2002; Parkhe, 1993) when there is an expectation of a long-term relationship. On the other hand, behavioral economists have ascribed trust to 'pro-social' preferences that distinctly diverge from economic rationality (Camerer, 2003). Verbeke and Greidanus (2009) regard trust as an unsatisfactory mechanism to constrain opportunism, in the absence of safeguards such as reputation or prior relationships. Instead, they propose that the opportunism view be replaced by the principle of bounded reliability. Even where there is trust, the priorities and preferences of actors may change. Firms may still act with self-interest, and may even do so out of benevolent intentions, but they may rearrange their priorities (for instance, because they lack internal resources and have overcommitted themselves), and thus choose to act in a seemingly selfish way, albeit without malevolent intentions. Such a transaction cost-inducing condition stems from an arguably common form of behavioral frailty in an uncertain and dynamically evolving environment and does not invoke opportunism defined as 'self-interest with guile' (Williamson, 1975). Bounded reliability acts as a complement to bounded rationality and also sheds light on the analysis of trust. Although psychological and social factors can facilitate trust between individuals, emotional or social bonds between well-intentioned economic agents can still be broken when exogenous shocks make it economically infeasible for them to adhere to their earlier commitments. Bounded reliability, in a sense, introduces limits to relying on the firm's past actions to determine its future deeds.

\section{THE PAPERS IN THE SPECIAL ISSUE}

Figure 1 represents a conventional view of modal choice outcomes, including markets, hierarchies, and hybrids, and of the economic cost-benefit logic (focusing on FSA bundling) leading to each of these outcomes. In different ways, all the papers in this special issue extend and challenge this convention. In particular, three themes emerge from these papers, revolving around (1) governance mechanisms that allow control to diverge from ownership and enable MNEs to utilize 'quasi-internalization' in trading-off the costs of the market against the costs of the hierarchy, (2) antecedents for the development of an MNE's transactional FSAs and for the effective deployment of these FSAs in its cross-border activities, and (3) institutional and cognitive reasons for an MNE's governance choices to deviate from the predictions of internalization theory based on the transaction cost-economizing logic.

\section{Unpacking Ownership and Control: The Rise of 'Quasi-Internalization'}

The changing definition of the MNE suggests its rapid evolution, as an MNE is now regarded as being an enterprise that engages in foreign direct investment (FDI) and owns-or through other means, 
controls-value-adding activities in several countries (Dunning \& Lundan, 2008: 3), shifting away from ownership as a key condition. This contrasts with the traditional view of the MNE, which has generally invoked the idea of ownership as a means to obtain control. For example, Buckley and Casson's (1976) knowledge market imperfections include the lack of control of what happens to the knowledge during and after the transaction. Hennart's (1989) arguments suggest that international market transactions may be associated with a failure to control foreign input or output quality, which in turn leads to suboptimal outcomes such as poor workmanship or reputational damage. In both cases, the failure to obtain control through the market justifies the hierarchical costs of internalization. Accordingly, until the 1990s, FDI and MNE activity were considered synonymous, because managing and coordinating foreign affiliates and enforcing contracts across borders were considered difficult and costly to achieve by other means.

However, although FDI is still one of the main modes by which MNEs engage in cross-border value-adding activities, today the MNE may also control and engage in value-adding activities through non-equity means, gaining de facto control over critical operations in the value chain without legal ownership of the factories where the operations are conducted. The conceptualization of the 'global factory' (Buckley, 2009), a network of activities led by a 'flagship firm' (Rugman \& D'Cruz, 1997), or the GVC (Gereffi, Humphrey, \& Sturgeon, 2005; Humphrey \& Schmitz, 2000; Kaplinsky \& Morris, 2001) underlines external networks between MNEs and other actors that rely on nonequity modes of engagement. GVCs are able to 'fine-slice' their activities and modularize various value-adding operations into a multitude of separate and distinct activities, utilizing a richer variety of organizational modes that lie between the fully internalized MNE and the market. These can best be described as 'quasi-internal' (Mowery, Oxley \& Silverman, 1996; Cantwell \& Narula, 2001; Narula $\&$ Santangelo, 2009). Some of the papers in the special issue explore this space, arguing for the need to theorize about new hybrid forms, or forms that are not already described in the established internalization literature.

The fragmentation of production by MNEs is closely associated with the costs of 'unbundling' operations spatially, as well as the degree of modularity of the production process (Baldwin \&
Venables, 2013; Elia, Massini \& Narula, 2019b; Asmussen, Larsen, \& Pedersen, 2016). GVCs are complex webs of customer-supplier relationships utilizing various governance modes, from direct ownership of foreign subsidiaries to contractual relationships and arm's-length dealings. The MNE may coordinate GVCs sometimes without de jure ownership of the productive assets but with de facto control over the operations of the nonaffiliated entities. GVCs have reduced the ownership boundaries of the firm by the use of quasi-internal (or quasi-market) ties with external actors, with the expectation that they can maintain the control boundaries of their supply chain. However, the larger the span of the GVC, the more bounded the rationality (Short et al., 2016). Monitoring and enforcement costs can shift the transaction cost logic towards greater vertical integration, even though in principle GVCs should be more efficient than hierarchically organized, integrated MNEs (Kano, 2017).

Drawing on global value chain literature and integrating it into internalization theory, the paper by Strange and Humphrey (2019) argues that there is much to be learnt from this interaction. In some senses, GVC-based analysis is the polar opposite of internalization, taking externalization as the steady state and seeking to understand the mechanisms to coordinate and control these externalized activities. The interdependencies within the network take center stage, just as the multinational firm and its associated cross-border transactions are at the heart of internalization.

This cross-pollination is still at an early stage, as Benito, Petersen and Welch (2019) also note. In particular, they claim that internalization theory can learn from GVC-based analysis in two ways: by having the entire value chain as its unit of analysis and thereby spotlighting the interdependencies, and by highlighting trust as a coordination mechanism that substitutes for behavioral control (e.g., contracting and monitoring). Indeed, as the literature on alliances has noted, there are often multiple, overlapping, and simultaneous agreements between collaborating firms, utilizing contractual, equity, and trust-based forms of governance in parallel. However, Benito et al. (2019) also point out that the costs of building and maintaining trust are not yet well understood. In fact, it is curious that the emphasis in the GVC literature is on coordination, rather than control. This is not just a difference in semantics or epistemology. Both Strange and Humphrey (2019) 
and Benito et al. (2019) suggest that the role of trust is a crucial difference; but, as we have discussed earlier, this reflects the uneasy relationship that internalization theory continues to have with its underlying assumption of bounded rationality and opportunism.

Not all non-market modes (such as GVCs) are alternatives to full vertical integration. Indeed, internalization theory has struggled somewhat with alliance formation, especially where this has a strategic aspect to it. Early commentary assumed that collaborative arrangements were inferior options to full internalization, but eventually the literature has coalesced towards accepting that quasi-internal governance modes were sometimes the optimal where the benefits from gaining access a foreign firm's assets that are also subject to market failure outweigh the transaction cost hazards related one's own assets (Hennart, 1988; Mudambi \& Tallman, 2010; Martínez-Noya \& Narula, 2018). A fair degree of cross-fertilization with strategic management has seen integration with resourcebased theory (Barney, 1991; Das \& Teng, 2000; Wernerfelt, 1984), the knowledge-based view and organizational learning theory (Kogut \& Zander, 1993), social network theory (Gulati, 1995; Powell \& Grodal, 2005), and the dynamic capabilities approach (Teece, Pisano \& Shuen, 1997; Zollo \& Winter, 2002). The growth of strategic alliances and outsourcing (especially when associated with innovation and $R \& D)$ has highlighted that value-optimization and long-term product market positioning can outweigh TCE considerations that are narrowly focused on the MNE's assets, especially since such partnering is part of a portfolio of overlapping short-term arrangements, and where the output may be tacit, or simply to enhance trust (Martínez-Noya \& Narula, 2018). The integration of concepts from resource-based theory into current thinking on internalization theory also distinguishes it from earlier versions that relied on a pure transaction cost perspective that regarded any strategic considerations as given.

The possibility to diverge de facto control from de jure control can also be used for strategic purposes other than reducing production or internal organization costs. Wang and Li (2019) argue that an MNE's ownership of a foreign entity that has been involved in a scandal can cause damage to the firm's reputation-often a key FSA of the MNE. Their analysis suggests that MNEs respond to reputational loss (or the risk of loss) along two dimensions of the governance structure: decreasing ownership so as to distance themselves from a scandal-ridden subsidiary, while at the same time trying to wrest more managerial control over it. This again points to the problem with equating the technical/legal boundary of the MNE with both its span of control and its sphere of accountability (Narula, 2019). In short, MNE managers may very well find that full control does not extend all the way to the boundary of the firm, but that accountability extends far beyond it-an observation that raises future research implications that we will return to and discuss below.

Finally, the complex relationship between ownership and control, and the advent of quasi-internalization, has become more evident than ever with the advent of digital technologies, as debated in an exchange in this special issue. Banalieva \& Dhanaraj (2019) argue that digital networks (such as that operated by Uber), can be considered as distinct modes of governance. Hennart (2019) vehemently disagrees, arguing that digital service MNEs as a category (as used by Banalieva \& Dhanaraj) is too broad a grouping, since these firms pursue a variety of new business models and that much of what they describe is simply hybrids that can be explained well by the existing theories.

Of course, complex organizational forms are not a uniquely modern phenomenon, as Da Silva Lopes, Casson \& Jones (2019) explain. Their paper avoids the 'traditional' dichotomy of market-versus-hierarchy, highlighting that, when faced with market imperfections, MNEs have often responded by modifying their organizational structure and the role of headquarters to effectuate more efficient knowledge transfer. Where circumstances have required it, firms have been able to be creative in adjusting the decision-making nexus within the MNE, using means of quasi-internalization, as illustrated in Figure 1.

\section{Unpacking Transactional FSAs: Antecedents of Trust and Control}

A corollary of the above arguments is that some of the benefits of internalization, including mutual adaptation and FSA recombination, can be reaped even in the absence of internalization, for example, throughout a self-coordinating GVC. However, just as internalization is not always necessary to obtain control, it may not always be sufficient, especially in a geographically dispersed hierarchy such as the MNE, where monitoring can become prohibitively expensive. This, in turn, suggests that not only the 
costs but also the benefits of internalization are endogenous to transactional FSAs.

A number of papers in the special issue explore this endogeneity by highlighting heterogeneity in transactional FSAs. In particular, the paper by Gaur, Pattnaik, Lee \& Singh (2019) focuses on the interaction between a business group's transaction-type FSAs and the costs and benefits of internalization. They argue that firms from such groups have developed capabilities to internally organize product and labor markets, in other words, $O_{T I}$ FSAs. However, since those FSAs were developed originally to correct market failures in their home countries, the quality of host market institutions is an important contingency for their ability to derive internalization-based benefits. Put differently, the $O_{T I}$ capabilities of business group MNEs may be location-bound, in the sense that they work well in home markets where they are developed to fill institutional voids, but perhaps less well in foreign markets where such voids are absent, or perhaps different from the ones at home.

Other than this observation, it is perhaps telling that the papers in this special issue have stayed away from locational issues within internalization theory, even as economic geography has come to rely on the tenets of internalization (Iammarino \& McCann, 2013; Mudambi et al., 2018). One of the issues that is repeatedly hinted on throughout this special issue is the systemic linkages within the economy, and the interdependencies between varieties of actors. Indeed, these lie at the heart of the GVC and innovation/geography literature. 'Trust' is associated with social systems, as Benito et al. (2019) tell us, and, indeed, the concept of multiple, ongoing transactions with the same actors within a system requires considering issues such as inertia, and high levels of inter-firm embeddedness that reflect long-term relationships. With fuzzy ownership boundaries but fairly firm control boundaries in certain GVC type organizations, these long-term quasi-internal relationships within such a milieu are arguably collectively a key FSA, as is the ability to select the most efficient governance mode (and to modify it for optimal coordination and efficiency over time). In that sense, transactional FSAs are also an important implicit or explicit component of GVC-based analysis, as discussed by Strange and Humphrey (2019). In order to be successful, the 'orchestrating' MNE in such a value chain needs to have capabilities to build and maintain productive relationships with a network of other geographically dispersed firms.
Finally, an additional reason why transactional FSAs have gained importance is that some of them are facilitated by technologies that have developed rapidly in recent years. The fusion or configuration of internal and external governance modes observed in digital networks is based on technological FSAs that, according to Banalieva \& Dhanaraj (2019), reduce transaction costs. They also propose that network-type FSAs are a resource distinct from traditional asset-type and transaction-type FSAs. Digital service MNEs, as they see it, are able to promote 'asset-light' internationalization by exploiting this special category of FSAs.

\section{Unpacking the Utility Function of Internalization: Biases and Inefficient Modal Choices}

The two previous themes focused on modal choice outcomes (markets, hierarchies, and quasi-internalization) and some of their antecedents (internal and external transactional FSAs), respectively. However, the causal link between the two remains, here as well as in the wider literature, decidedly based on the logic of economic efficiency. Two papers in this special issue aim to examine the influences of additional causal linkages by challenging internalization theory's 'rational action' paradigm.

Elia, Larsen and Piscitello (2019a) apply a behavioral economics/cognitive psychology lens (e.g., Tversky \& Kahneman, 1974; Thaler, 2016) to complement the bounded rationality approach to understanding MNE behavior. Beyond the bounded rationality of imperfect and incomplete information, the decisions of MNE managers may also be shaped by a variety of biases and cognitive limitations. Actors make judgements based on heuristics derived from limited experience. These restrain their ability to make optimal decisions. This implies that governance mode choices (like location choices; see Buckley, Devinney \& Louviere, 2007) may deviate in systematic ways from the predictions of the theory.

Grøgaard, Rygh, and Benito (2019) expand the scope of the theory to encompass SOEs. Based on the corporate governance literature, they argue and show that these less-conventional firms indeed make governance mode choices that differ from private firms-but that the differences disappear if their home country institutions are sufficiently developed. Their work suggests that the nature of home institutions can cause the choices of SOEs to deviate from the theoretically predicted optimum, while the work of Elia et al. (2019a, b) suggests that 
past experience in the presence of cognitive limitations can do the same to even private firms.

Both of these arguments have implications for competition, selection, and performance of MNEs. A common predicament of both SOE managers (and managers who are biased by their positive or negative experiences) is that they would find themselves suffering competitive disadvantages compared to firms that pursue more rational strategies. An 'over-internalizing' firm (internalizing activities even when the benefits do not justify the costs of internalization) would be at a disadvantage against a more agile network of firms conducting market- or relationship-based transactions without being burdened by the MNE hierarchy. An 'under-internalizing' firm (failing to internalize activities even when the benefits do justify the costs), on the other hand, would be at a disadvantage against MNEs who can leverage the benefits of global integration against it.

Depending on how strong the market selection mechanisms are, and the extent to which the owners can continue to subsidize unprofitable firms, this situation may be more or less sustainable in the long run. For state-owned enterprises, this might be a long time, as home governments can tap into large capital reserves and raise more capital through taxation. However, as the quality of institutions improves, subsidization possibilities may be circumscribed, consistent with the results of Grøgaard et al. (2019). For firms that do not have the advantage of state ownership, but are merely pursuing suboptimal strategies due to psychological biases (Elia et al., 2019a, b), we can speculate that the deviations are likely to be more persistent in industries with weak competition, or possibly when participants enjoy unique and hardto-imitate resources.

\section{FUTURE RESEARCH}

Special issues on contemporary subjects represent a moving target: Changes in the socio-economic reality within which international business is undertaken continue to evolve. As Buckley and Casson (2019) point out, internalization theory-in its essence-has been proven to be resilient yet flexible, and, despite disagreements as to its scope of application, serves both as a basis to formulate the existential questions about the firm and the scope and scale of its activities, and a tool for managers and policy makers alike to make reasoned analyses. It is perhaps inevitable that there are a number of new questions that need to be answered, since IB research crosses so many disciplinary boundaries. We highlight a selection of these here. It is important to note that, in proposing this research agenda, we address both audiences-the IB 'specialists' for whom internalization is a theory, and for IB 'generalists' for whom internalization provides an organizing framework.

\section{Fuzziness and Divergence in the Boundaries of the MNE for Ownership, Control and Responsibility}

In a sense, it is easy to see that we must return to Coase's original and deceptively simple formulation, and revisit the question of boundaries of the firm (and the MNE). We have discussed earlier that the original understanding of the MNE no longer sees the ownership boundaries and the control boundaries of the firm as being largely congruent or overlapping. This is a case of 'fuzzy boundaries', where legal or fiscal ownership does not imply control, or vice versa, although there is no hard and fast rule. International financial statistics assume a $10 \%$ or $20 \%$ foreign ownership stake to mean that the MNE has control, and is therefore a foreign direct investment. Yet, this benchmark nowadays is archaic and increasingly irrelevant. Coca-Cola or McDonalds may not own their bottling plants or restaurants, yet they both exert almost complete control over these establishments through effective means of partitioning and enforcing the property rights to the operations. We may need to distinguish between subsidiary operations and affiliated operations, because each implies a significant-if nuanced-difference. Complete ownership does not guarantee control either, as the research on subsidiary embeddedness shows.

The complexity of GVCs, and the infinite variety in forms of control and ownership, raise a variety of issues. Control boundaries can be simple, because contracts can establish subsidiarity, but the same supplier may serve multiple MNEs. Flex does not own the products it manufactures for Apple (or those of its other customers for whom it assembles mobile phones); it is a conduit between two Apple subsidiaries. Flex's facilities for production are typically actively monitored and the contents owned by the customer.

There is now a third boundary to consider: the responsibility boundary (Egels-Zandén, 2017). One of the implicit benefits from outsourcing had been the MNE's reduced culpability for the actions (or inactions) of its suppliers when delivering 
outsourced goods and services. Yet, consumers, NGOs and nation states increasingly hold the MNE accountable for ethical and social lapses by any actors within its supply chain. These three boundaries-ownership, control, and responsibilityhave different spans. While ownership boundaries may have receded in a GVC, control has a wider span, while the firm's responsibility boundaries now stretch much further than do its control boundaries (Narula, 2019). In that context, the MNE's 'social brand' can be considered a particular type of non-location-bound FSA, which can be built-but more importantly also destroyed-on a global scale (Asmussen \& Fosfuri, 2019). Greater responsibility boundaries are incompatible with reduced control, and the increased transaction costs of exerting 'full-chain responsibility' are non-negligible (Narula, 2019). To what degree should we regard a firm's supply chain as quasiinternal, if the MNE suffers a diminution of its reputational FSAs? What are the advantages of quasi-internal modes of governance in a GVC if the lead firm (the MNE) bears the cost of monitoring and enforcing standards across the entire supply chain?

\section{Boundary-Augmenting FSAs: Antecedents and Consequences}

The MNE as 'a nexus of transactions' played a significant role in internalization theory in its earlier incarnations, understating the importance of the firm as a function of its 'stock' of proprietary knowledge. Later versions painted a more realistic picture, with the MNE as a curator of this knowledge, embodied in its human and physical capital. As much as its capacity to engage in intra- and inter-firm transactions, the MNE is dependent on efficiently maintaining, utilizing, and enhancing these FSAs. The last two decades have seen a growing debate on the nature and relevance of FSAs. Cantwell, Dunning \& Lundan (2010) introduced $O_{I}$ advantages, associated with knowledge of institutions, in addition to the 'classic' $O_{A}$ and $O_{T}$ FSAs, while Verbeke (2013) and Narula (2014) have emphasized the role of recombinant FSAs $\left(O_{R}\right)$. This special issue has raised the specter of further categories and subcategories of FSAs (including $O_{T I}$ and $O_{T E}$ in this introduction), but, ultimately, the benefit of doing so is to better understand the 'why' and the 'how' of international business, with the 'how' discussion having expanded from focusing on the ideal governance structure to the optimal method to greater efficiency. In doing so, it is worth noting-once again-that MNEs are complex, unique, and idiosyncratic and path-dependent. Just as there is no 'the' firm (Nightingale, 2008), there is no stereotypical MNE. Expanded categorization of FSA types is key to appreciating this diversity.

Recognizing this diversity, internalization theory research has acknowledged that MNEs are driven by a variety of multiple and overlapping motives to engage in cross-border activities (Dunning, 1993; Cuervo-Cazurra et al., 2015). Considerable scholarship has built towards understanding how the motives of MNE investment have been evolving (Benito, 2015). In particular, the growing tendency towards asset-augmenting activity (Dunning \& Narula, 1995; Cantwell \& Narula, 2001; Meyer, 2015) has created an important link to the innovation activities of MNEs (Pearce, 1999; Castellani \& Zanfei, 2006; Cantwell, 2017). Greater interest was also directed towards a more fine-grained view of the MNE, as the role of the subsidiary has become more vital, reflected in the growing importance of competence-creating subsidiaries (Cantwell \& Mudambi, 2005) and reverse innovation in MNEs (Frost \& Zhou, 2005; Alcácer \& Zhao, 2012; Rabbiosi \& Santangelo, 2013). There is concomitantly a more explicit realization that substantial costs arise from managing increasingly complex organizations and combining external and internal embeddedness in dispersed subsidiaries (Narula, 2014).

In this paper, we have sought to further investigate is the dynamics of transactional FSAs. As discussed above, and in several of the special issue papers, and illustrated in Figure 1, capabilities to organize internal $\left(O_{T I}\right)$ or external $\left(O_{T E}\right)$ transactions are arguably increasingly important drivers of modal choices. However, where do such capabilities come from in the first place? If they are mostly endogenous to experience, what does that say about the possibility of establishing causality, an important criterion for which is temporal precedence? Indeed, Hennart (2019) suggests that a theory based on such FSAs borders on the tautological, because they can only be observed ex post through the degree of the success of the MNE's international operations, reflecting a more fundamental issue that also applies to the wider realm of the RBV (Priem \& Butler, 2001; Cockburn, Henderson, \& Stern, 2000). Perhaps this implies that we need to take one step further back and ask which firm- or location-specific factors are likely to influence $O_{T I}$ and $O_{T E}$. The paper by Gaur et al. (2019) provides a candidate in the form of business group 
membership, and future research can strive to identify more such antecedents. However, it is also possible that a more dynamic approach has to be adopted in order to theoretically model and empirically examine how transactional capabilities and international operations, hierarchical or relationship-based, co-evolve and influence each other over time.

A more careful look into the properties of the transactional FSAs can help us explore the implications of $O_{T I}$ and $O_{T E}$ for the international scope and diversity of the MNE's activities. A rise in the firm's $O_{T I}\left(O_{T E}\right)$ can be expected to enhance its ability to expand its international scope and diversity via internalization (quasi-internalization). Given that both $O_{T I}$ and $O_{T E}$ are scarce resources, accumulated over time through human resource and organization development, and that their deployment inevitably raises demands on the finite attention of the firm's top executives, each type of transactional FSAs is likely to exhibit diminishing returns. An interesting question is, however, whether an MNE can develop and deploy the two types of transactional FSAs in a substitutive or complementary manner? If $O_{T I}$ and $O_{T E}$ entail largely similar human skills and organizational routines, their development will be mutually reinforcing. If they entail different types of skills and routines; however, a firm may need to focus on one type or the other. Similarly, even though joint use of $O_{T I}$ and $O_{T E}$ in the MNE's activities may help optimize transactional efficiency in international expansion, the efficacy of the different governance modes may to a large extent depend on the transaction cost properties of the location-bound FSAs that the MNE wishes to access overseas, constraining the joint deployment of $O_{T I}$ and $O_{T E}$ in the same MNE. The extent to which $O_{T I}$ and $O_{T E}$ are complements or substitutes is a question that may deserve careful attention in future research.

\section{Location, Distance, and International Diversity of MNE Activities}

An issue that the papers in this special issue have largely stayed away from is the role of location. However, as Pitelis and Verbeke (2007) point out, what makes internalization theory different from transaction cost economics is the role of location; hence, 'a theory of MNE growth ... needs to address the impact of distance'. Goerzen and Beamish (2003) suggest that transaction costs are likely to increase with distance, which can be broadly defined to include geographic, economic, cultural, and institutional dimensions (Ghemawat, 2007). The effect of distance can be added to the analytical framework outlined in Figure 1.

When trying to recombine their respective FSAs, the MNE and the local firm are likely to face greater difficulty in mitigating market imperfections for the FSAs as the distance between the locations of the FSAs increases, because information asymmetries become more severe and monitoring more expensive. If transaction cost problems associated with the MNE's (local firm's) FSAs escalate more rapidly with distance than those affecting the local firm's (MNE's) FSAs, the optimal governance mode will shift from the market to internalization (quasiinternalization), along the arrowed line in the northwest (southeast) region of Figure 1. In each case, the frictions due to geographic, economic, cultural, and institutional distances may grow so large that they are unable to realize the potential value from the recombination of their FSAs, falling into the region of irremediable market failure in the diagram.

Distance has implications not only for the choice of governance mode in a specific case of FSA combination but also for the international diversity of the MNE's activities, defined here as the aggregate distances across all the MNE's FSA recombination activities. The marginal cost of organizing its FSA recombination activities internally or externally is likely to grow after passing a certain threshold, imposing a natural upper limit to the international diversity of the MNE. In the meantime, strong $O_{T I}$ and/or $O_{T E}$ capabilities could expand the area in the middle of the diagram where either internalization or quasi-internalization is optimal. This would have two consequences: at low diversity, enhanced $O_{T I}\left(O_{T E}\right)$ will lead to internalization (quasi-internalization) in scenarios where the market would otherwise have prevailed. Hence, transactional FSAs might allow subtle recombination of FSAs, which might be observed empirically as very slight adaptations of products and processes and tight coordination between proximate units, either in a regional MNE or a regional value chain (Verbeke \& Asmussen, 2016). At high diversity, on the other hand, enhanced $O_{T I}$ $\left(O_{T E}\right)$ will lead to internalization (quasi-internalization) in scenarios where irremediable market failure would otherwise have occurred. This might lead the MNE to establish subsidiaries in markets that it would previously have avoided. Hence, depending on the type and strength of an MNE's transactional FSAs, $O_{T I}$ and $O_{T E}$ can enlarge its boundaries of both 
ownership and control or expand the boundary of its control but reducing the boundary of its ownership. The consideration of the potentially differential influences from $O_{T I}$ and $O_{T E}$ may also provide insight into the tangled relationship between multinationality and performance (Berry \& Kaul, 2016; Hennart, 2007; Verbeke \& Forootan, 2012).

\section{CONCLUSIONS}

At a high level, the papers in the special issue demonstrate that internalization theory (broadly defined) is still a powerful framework, and that there is significant potential for using its components in a modular fashion in extending the framework and integrating it with complementary concepts from other theories. At the same time, there is always a need for prudence and commensurability in developing new theories. First, even though it was originally developed to explain the emergence of large manufacturing MNEs in the post-WWII era, the basic analytical approach of the theory is arguably still applicable to explaining the boundary choices by other types of MNEs in different time periods such as those from emerging economies (Verbeke \& Kano, 2015), sponsored by the state (Grøgaard et al., 2019), run by a single family (Hennart et al., 2017), or focusing on digital services (Banalieva \& Dhanaraj, 2019; Hennart, 2019). Therefore, a judicious approach to studying a seemingly new type of transaction or firm is perhaps first to assess carefully whether internalization theory still has substantial explanatory power to effectively explain the 'new' governance mode, transaction, or firm.

Second, while it seems promising to integrate concepts from a different theory with internalization theory, it is still important to examine carefully whether the two theories are commensurate in assumptions and analytic logic (e.g., level of the decision-maker's rationality). If not, the difference should be recognized, so that the development of a new or more integrative approach can be explicit about which assumption of internalization theory is being relaxed or modified to attain analytical clarity and logical consistency. Formal modeling is

\section{REFERENCES}

Alcácer, J., \& Zhao, M. 2012. Local R\&D strategies and multilocation firms: The role of internal linkages. Management Science, 58(4): 734-753. a promising, but underutilized, approach in this endeavor. Explicit theorizing is particularly important in introducing concepts from sister social science disciplines, such as sociology and psychology, e.g., in studying influences of institutional embeddedness and psychological biases.

The papers in this special issue fulfill an important function in bringing these issues to the forefront of the research agenda. It is our hope that, in combination, they might serve not only to delineate current frontiers in international business research but also inspire work on new (and as yet unidentified) ones. Building on this work should ensure ample opportunities both for empirical researchers looking to apply internalization theory and for theoretical researchers looking to advance it.

\section{ACKNOWLEDGEMENT}

We thank JIBS Editor-in-Chief Alain Verbeke for guidance and helpful comments on earlier versions of this manuscript.

\section{NOTES}

${ }^{1}$ See also Cantwell (2015) for a dissenting view.

${ }^{2}$ Market failure refers to the condition that market transactions are less efficient than under some alternative mode of organization such as administrative fiat inside the firm. It does not necessarily signify a failure so severe that the market transactions generate no positive value for the exchange parties. Some authors (e.g., Rugman, 1981) prefer to use the term 'market imperfections' instead. We use these two terms interchangeably in this paper.

${ }^{3}$ The FSAs of some MNEs (particularly those from emerging economies) may be location-bound to a large extent (e.g., expertise in efficient manufacturing in their home country), and their international expansion may initially be motivated primarily by the desire to acquire non-location-bound FSAs (e.g., advanced R\&D capabilities).

Ambos, B., Kunisch, S., Leicht-Deobald, U., \& Steinberg, S. 2019. Unravelling agency relations inside the MNC: The roles of socialization, goal conflicts and second principals in 
headquarters-subsidiary relationships. Journal of World Business, 54(2): 67-81.

Asmussen, C. G. 2009. Local, Regional, or global? Quantifying MNE geographic scope. Journal of International Business Studies, 40(7): 1192-1205.

Asmussen, C. G., \& Fosfuri, A. 2019. Orchestrating corporate social responsibility in the multinational enterprise. Strategic Management Journal, 40(6): 894-916.

Asmussen, C. G., \& Goerzen, A. 2013. Unpacking dimensions of foreignness: Firm-specific capabilities and international dispersion in regional, cultural, and institutional space. Global Strategy Journal, 3(2): 127-149.

Asmussen, C. G., Larsen, M. M., \& Pedersen, T. 2016. Organizational adaptation in offshoring: The relative performance of home- and host-based learning strategies. Organization Science, 27(4): 911-928.

Asmussen, C. G., Pedersen, T., \& Dhanaraj, C. 2009. Hostcountry environment and subsidiary competence: Extending the diamond network model. Journal of International Business Studies, 40(1): 42-57.

Baker, G., Gibbons, R., \& Murphy, K. J. 1994. Subjective performance measures in optimal incentive contracts. The Quarterly Journal of Economics, 109(4): 1125-1156.

Baker, G., Gibbons, R., \& Murphy, K. J., 2002. Relational contracts and the theory of the firm. The Quarterly Journal of Economics, 117(1): 39-84.

Baldwin, R., \& Venables, A. J., 2013. Spiders and snakes: offshoring and agglomeration in the global economy. Journal of International Economics, 90(2): 245-254.

Banalieva, E., \& Dhanaraj, C. 2019. Internalization theory for the digital economy. Journal of International Business Studies. https://doi.org/10.1057/s41267-019-00243-7.

Barney, J. B. 1991. Firm resources and sustained competitive advantage. Journal of Management, 17(1): 99-120.

Benito, G. R. 2015. Why and how motives (still) matter. The Multinational Business Review, 23(1): 15-24.

Benito, G. R., Petersen, B., \& Welch, L. S. 2019. The global value chain and internalization theory. Journal of International Business Studies. https://doi.org/10.1057/s41267-019-002188.

Berry, H., \& Kaul, A. 2016. Replicating the multinationalityperformance relationship: Is there an S-curve? Strategic Management Journal, 37(11): 2275-2290.

Birkinshaw, J., \& Pedersen, T., 2001. Strategy and management in MNE subsidiaries. In A.M. Rugman \& T. Brewer (Eds), The Oxford handbook of international business: 380-401. New York: Oxford University Press.

Buckley, P. J. 2009. The impact of the global factory on economic development. Journal of World Business, 44: $131-143$.

Buckley, P. J., \& Casson, M. 1976. The Future of the Multinational Enterprise (Vol. 1). London: Macmillan.

Buckley, P. J., \& Casson, M. C. 1998a. Models of the multinational enterprise. Journal of International Business Studies, 29(1): 21-44.

Buckley, P. J., \& Casson, M. C. 1998b. Analyzing foreign market entry strategies: Extending the internalization approach. Journal of International Business Studies, 29(3): 539-562.

Buckley, P. J. \& Casson, M. C., 2009. The internalisation theory of the multinational enterprise: A review of the progress of a research agenda after 30 years. Journal of International Business Studies, 40(9): 1563-1580.

Buckley, P. J., \& Casson, M. 2019. Decision making in international business. Journal of International Business Studies. https://doi.org/10.1057/s41267-019-00244-6.

Buckley, P. J., Devinney, T. M. \& Louviere, J. J., 2007. Do managers behave the way theory suggests? A choice-theoretic examination of foreign direct investment location decisionmaking. Journal of International Business Studies, 38(7): 1069-1094.
Buckley, P. J., \& Hashai, N. 2002. Formalizing internationalization in the eclectic paradigm. Journal of International Business Studies, 40(1): 58-70.

Camerer, C. F., 2003. Strategizing in the brain. Science, 300(5626): 1673-1675.

Cantwell J. 2015. The eclectic paradigm a framework for synthesizing and comparing theories of international business from different disciplines or perspectives. London: Palgrave Macmillan.

Cantwell, J., 2017. Innovation and international business. Industry and Innovation, 24(1): 41-60.

Cantwell, J., Dunning, J. H., \& Lundan, S. M. 2010. An evolutionary approach to understanding international business activity: The co-evolution of MNEs and the institutional environment. Journal of International Business Studies, 41(4): 567-586.

Cantwell, J., \& Mudambi, R. 2005. MNE competence-creating subsidiary mandates. Strategic Management Journal, 26(12): 1109-1128.

Cantwell, J., \& Narula, R. 2001. The eclectic paradigm in the global economy. International Journal of the Economics of Business, 8(2): 155-172.

Casson, M. C., \& Wadeson, N. 2012. The economic theory of international business: A supply chain perspective. Multinational Business Review, 20(2): 114-134.

Castellani, D., \& Zanfei, A. 2006. Multinational firms, innovation and productivity. Cheltenham: Edward Elgar.

Chi, T. 1994. Trading in strategic resources: Necessary conditions, transaction cost problems, and choice of exchange structure. Strategic Management Journal, 15: 271-290.

Chi, T. 1996. Performance verifiability and output sharing in collaborative ventures. Management Science, 42(1): 93-109.

Chi, T. 2015. Commentary: Internalization theory and its relation to RBV and TCE. Journal of World Business, 50: 634-636.

Chi, T., \& Nystrom, P. 1998. An economic analysis of matrix structure, using multinational corporations as an illustration. Managerial and Decision Economics, 19(3): 141-156.

Chi, T., \& Roehl, T. W. 1997. The structuring of interfirm exchanges in business know-how: Evidence from international collaborative ventures. Managerial and Decision Economics, 18(4): 279-294.

Chi, T., \& Zhao, Z. J. 2014. Equity structure of MNE affiliates and scope of their activities: Distinguishing the incentive and control effects of ownership. Global Strategy Journal, 4(4): 257-279.

Coase, R. H. 1960. The problem of social cost. Journal of Law and Economics, 3: 1-44.

Cockburn, I. M., Henderson, R. M., \& Stern, S., 2000. Untangling the origins of competitive advantage. Strategic Management lournal, 21(10-11): 1123-1145.

Cohen, W., \& Levinthal, D. (1990). Absorptive capacity: A new perspective on learning and innovation. Administrative Science Quarterly, 35(1): 128-152.

Collinson, S., \& Narula, R. 2014. Asset recombination in international partnerships as a source of improved innovation capabilities in China. Multinational Business Review, 22(4): 394-417.

Cuervo-Cazurra, A. 2012. Extending theory by analyzing developing country multinational companies: Solving the Goldilocks debate. Global Strategy Journal, 2(3): 168-187.

Cuervo-Cazurra, A., Narula, R. \& Un, C. A., 2015. Internationalization motives: sell more, buy better, upgrade and escape. The Multinational Business Review, 23(1): 25-35.

Cullen, J. B., Johnson, J. L., \& Sakano, T. 2000. Success through commitment and trust: The soft side of strategic alliance management. Journal of World Business, 35(3): 223-240.

Da Silva Lopes, T., Casson, M., \& Jones, G. 2019. Organizational innovation in the multinational enterprise: Internalization theory and business history. Journal of International Business Studies. https://doi.org/10.1057/s41267-018-0156-6. 
Das, T. K., \& Teng, B. S. 2000. A resource-based theory of strategic alliances. Journal of Management, 26(1): 31-61.

Das, T. K., \& Teng, B. S. 2001. Trust, control, and risk in strategic alliances: An integrated framework. Organization Studies, 22(2): 251-283.

Dhanaraj, C., \& Parkhe, A. 2006. Orchestrating innovation networks. Academy of Management Review, 31(3): 659-669.

Duhigg, C., \& Bradsher, K. 2012. How the U.S. lost out on iPhone work. New York Times, January 22. https://www.nytimes.com/ 2012/01/22/business/apple-america-and-a-squeezed-middleclass.html.

Dunning, J. H. 1977. Trade, location of economic activity and the MNE: A search for an eclectic approach. In P.-O. Hesselborn, B. Ohlin, \& P.M. Wijkman (Eds), The international allocation of economic activity: 395-418. London: Palgrave Macmillan.

Dunning, J. H. 1993. Internationalizing Porter's diamond. Management International Review, 33(2-1): 7-16.

Dunning, J. H. 1995. Reappraising the Eclectic Paradigm in an age of alliance capitalism. Journal of International Business Studies, 26(3): 461-491.

Dunning, J. H. 2000. The eclectic paradigm as an envelope for economic and business theories of MNE activity. International Business Review, 9(2): 163-190.

Dunning, J. H., \& Lundan, S. M. 2008. Multinational enterprises and the global economy. Cheltenham: Edward Elgar.

Dunning, l. H., \& Lundan, S. M. 2009. The internationalization of Corporate R\&D: A review of the evidence and some policy implications for home countries 1. Review of Policy Research, 26(1-2): 13-33.

Dunning, J. H., \& Narula, R. 1995. The R\&D activities of foreign firms in the United States. International Studies of Management \& Organization, 25(1-2): 39-74.

Dunning, J. H., \& Rugman, A. M. 1985. The influence of Hymer's dissertation on the theory of foreign direct investment. The American Economic Review, 75(2): 228-232.

Eden, L., \& Dai, L. 2010. Rethinking the O in Dunning's OLI/ eclectic paradigm. Multinational Business Review, 18(2): 13-34.

Edström, A., \& Galbraith, J. R. 1977. Transfer of managers as a coordination and control strategy in multinational organizations. Administrative Science Quarterly, 248-263.

Egels-Zandén, N. 2017. Responsibility boundaries in global value chains: Supplier audit prioritizations and moral disengagement among Swedish firms. Journal of Business Ethics, 146(3): 515-528.

Elia, S., Larsen, M. M., \& Piscitello, L. 2019a. Entry mode deviation: A behavioral approach to internalization theory. Journal of International Business Studies. https://doi.org/10. 1057/s41267-019-00235-7.

Elia, S., Massini, S., \& Narula, R. 2019b. Disintegration, modularity and entry mode choice: Mirroring technical and organizational architectures in business functions offshoring. Journal of Business Research, 103: 417-431.

Foss, M. J., \& Weber, L. 2016a. Moving opportunism to the back seat: Bounded rationality, costly conflict, and hierarchical forms. Academy of Management Review, 41(1): 61-79.

Foss, M. J., \& Weber, L. 2016b. Expand bounded rationality, but don't throw opportunism out of the car and under the bus: A reply to Lumineau and Verbeke. Academy of Management Review, 41(4): 741-744.

Frost, T. S., \& Zhou, C. 2005. R\&D co-practice and 'reverse' knowledge integration in multinational firms. Journal of International Business Studies, 36(6): 676-687.

Gaur, A., Pattnaik, C., Lee, J. Y., \& Singh, D. 2019. Internalization advantage and subsidiary performance: The role of business group affiliation and host country characteristics. Journal of International Business Studies. https://doi.org/10. 1057/s41267-019-00236-6.

Gereffi, G., Humphrey, J., \& Sturgeon, T. 2005. The governance of global value chains. Review of International Political Economy, 12(1): 78-104.
Ghemawat, P. 2007. Managing differences: The central challenge of global strategy. Harvard Business Review, 85(3): $58-68$.

Goerzen, A., \& Beamish, P.W. 2003. Geographic scope and multinational enterprise performance. Strategic Management Journal, 24(13): 1289-1306.

Grøgaard, B., Rygh, A., \& Benito, G. 2019. Bringing corporate governance into internalization theory: State ownership and foreign entry strategies. Journal of International Business Studies. https://doi.org/10.1057/s41267-019-00237-5.

Grossman, S., \& Hart, O. 1986. The costs and benefits of ownership: A theory of vertical and lateral integration, Journal of Political Economy, 94(4): 691-796.

Gulati, R. 1995. Does familiarity breed trust? The implications of repeated ties for contractual choice in alliances. Academy of Management Journal, 38(1): 85-112.

Hagedoorn, J. 1993. Understanding the rationale of strategic technology partnering: interorganizational modes of cooperation and sectoral differences. Strategic Management Journal, 14(5): 371-385.

Hamel, G., 1991. Competition for competence and interpartner learning within international strategic alliances. Strategic Management Journal, 12(S1): 83-103.

Hamel, G., Doz, Y., \& Prahalad, C. K. 1989. Collaborate with your competitors-and win. Harvard Business Review, JanuaryFebruary: 133-139.

Harris, M., \& Raviv, A. 1979. Optimal incentive contracts with imperfect information. Journal of Economic Theory, 20(2): 231-259.

Hennart, J. F. 1977. A theory of foreign direct investment. Ph.D. Dissertation, University of Maryland, College Park, MD.

Hennart, J. F. 1982. A theory of multinational enterprise. Ann Arbor, MI: University of Michigan.

Hennart, J. F. 1988. A transaction costs theory of equity joint ventures. Strategic Management Journal, 9(4): 361-374.

Hennart, J. F. 1989. Transaction costs theory and the multinational enterprise. In C. N. Pitelis, \& R. Sugden (Eds), The nature of the transnational firm: 81-116. London: Routledge.

Hennart, J. F. 1993. Explaining the swollen middle: Why most transactions are a mix of 'Market' and 'Hierarchy', Organization Science, 4(4): 529-547.

Hennart, J. F. 2007. The theoretical rationale for a multinationality/performance relationship. Management International Review, 47(3): 307-317.

Hennart, J. F. 2009. Down with MNE-centric theories! Market entry and expansion as the bundling of MNE and local assets. Journal of International Business Studies, 40(9): 1432-1454.

Hennart, J. F. 2012. Emerging market multinationals and the theory of the multinational enterprise. Global Strategy Journal, 2(3): 168-187.

Hennart, J. F. 2014. The accidental internationalists: A theory of born globals. Entrepreneurship Theory and Practice, 38(1): 117-135.

Hennart, J. F. 2019. Digitalized service multinationals and international business theory. Journal of International Business Studies. https://doi.org/10.1057/s41267-019-00256-2.

Hennart, J. F., Majocchi, A., \& Forlani, E. 2017. The myth of the stay-at-home family firm: How family-managed SMEs can overcome their internationalization limitations. Journal of International Business Studies, 50: 758-782. https://doi.org/ 10.1057/s41267-017-0091-y.

Humphrey, J., \& Schmitz, H. 2000. Governance and upgrading: Linking industrial cluster and global value chain research (Vol. 120). Brighton: Institute of Development Studies.

Hymer, S. H. 1960 (published 1976). The international operations of national firms: A study of direct foreign investment. Cambridge, MA: MIT Press.

lammarino, S., \& McCann, P. 2013. Multinationals and economic geography: Location, technology and innovation. Cheltenham: Edward Elgar. 
Kano, L., 2017. Global value chain governance: A relational perspective. Journal of International Business Studies, 1-22.

Kaplinsky, R., \& Morris, M. 2001. A manual for value chain research. Brighton: IDS, University of Sussex.

Klein, B., \& Murphy, K. M. 1997. Vertical integration as a selfenforcing contractual arrangement. American Economic Review, 87(2):415-420.

Kogut, B., \& Zander, U. 1993. Knowledge of the firm and the evolutionary theory of the multinational corporation. Journal of International Business Studies, 24(4): 625-645.

Lumineau, F., \& Verbeke, A. 2016. Let's give opportunism the proper back seat. Academy of Management Review, 41(4): 739-741.

Madhok, A. 2015. Commentary: A critical assessment of firm advantage and implications for multinationals and multinationalizing firms. Journal of World Business, 50(4): 627-630.

Martínez-Noya, A., \& Narula, R. 2018. What more can we learn from R\&D alliances? A review and research agenda. Business Research Quarterly, 21: 195-212.

Meyer, K. 2015. What is "strategic asset seeking FDI"? The Multinational Business Review, 23(1): 57-66.

Montgomery, C. A., \& Wernerfelt, B. 1988. Diversification, Ricardian rents, and Tobin's q. RAND Journal of Economics, 19(4): 623-632.

Mowery, D. C., Oxley, J. E. \& Silverman, B. S. 1996. Strategic alliances and interfirm knowledge transfer. Strategic Management Journal, 17(S2): 77-91.

Mudambi, R., Narula, R., \& Santangelo, G. 2018. Location, collocation and innovation by multinational enterprises: A research agenda. Industry and innovation, 25(3): 229-241.

Mudambi, S. M., \& Tallman, S. 2010. Make, buy or ally? Theoretical perspectives on knowledge process outsourcing through alliances. Journal of Management Studies, 47(8): 1434-1456.

Narula, R. 2010. Keeping the eclectic paradigm simple. Multinational Business Review, 18(1): 35-50.

Narula, R. 2012. Do we need different frameworks to explain infant MNEs from developing countries? Global Strategy Journal, 2(1), 41-47.

Narula, R. 2014. Exploring the paradox of competence-creating subsidiaries: balancing bandwidth and dispersion in MNEs. Long Range Planning, 47(1-2): 4-15.

Narula, R. 2017. Emerging market MNEs as meta-integrators: The importance of internal networks. International Journal of Technology Management, 74(1/2/3/4): 214-220.

Narula, R. 2019. Enforcing higher labour standards within developing country supply chains: Consequences for informal actors in a dual economy. Journal of International Business Studies, 50(9).

Narula, R., \& Hagedoorn, J. 1999. Innovating through strategic alliances: Moving towards international partnerships and contractual agreements. Technovation, 19(5): 283-294.

Narula, R., \& Santangelo, G. D. 2009. Location, collocation and $\mathrm{R} \& \mathrm{D}$ alliances in the European ICT industry. Research Policy 38: 393-403.

Narula, R., \& Santangelo, G. D., 2012. Location and collocation advantages in international innovation. Multinational Business Review, 20(1): 6-25.

Narula, R., \& Verbeke, A. 2015. Making internalization theory good for practice: The essence of Alan Rugman's contributions to international business. Journal of World Business, 50(4): 612-622.

Nightingale, P. 2008. Meta-paradigm change and the theory of the firm. Industrial and Corporate Change, 17(3): 533-583.

Ouchi, W. G. 1979. A conceptual framework for the design of organizational control mechanisms. Management Science, 25(9): 833-848.

Parkhe, A. 1993. Strategic alliance structuring: A game theoretic and transaction cost examination of interfirm cooperation. Academy of Management Journal, 36: 794-829.
Pearce, R. 1999. The evolution of technology in multinational enterprises: the role of creative subsidiaries. International Business Review, 8(2): 125-148.

Penrose, E. T. 1959. The theory of the growth of the firm. Oxford: Wiley.

Pitelis, C., \& Verbeke, A. 2007. Edith Penrose and the future of the multinational enterprise. Management International Review, 47: 139-149.

Powell, W. W., \& Grodal, S. 2005. Networks of innovators. The Oxford handbook of innovation, 78.

Priem, R. L. \& Butler, J. E. 2001. Is the resource-based "view" a useful perspective for strategic management research? Academy of Management Review, 26(1): 22-40.

Rabbiosi, L., \& Santangelo, G. D. 2013. Parent company benefits from reverse knowledge transfer: The role of the liability of newness in MNEs. Journal of World Business, 48: 160-170.

Reuer, J. J., \& Zollo, M., 2005. Termination outcomes of research alliances. Research Policy, 34(1): 101-115.

Roehl, T. W., \& Truitt, J. F. 1987. Stormy open marriages are better: Evidence from US, Japanese and French cooperative ventures in commercial aircraft. Columbia Journal of World Business, 22(2): 87-95.

Rugman, A. M. 1981. Inside the multinationals: The economics of internal markets. New York: Columbia University Press.

Rugman, A. M. 2005. The regional multinationals: MNEs and global strategic management. Cambridge: Cambridge University Press.

Rugman, A. M., \& D'Cruz, J. 1997. The theory of the flagship firm. European Management Journal, 15(4): 403-412.

Rugman, A. M. \& Verbeke, A. 1992. A note on the transnational solution and the transaction cost theory of multinational strategic management. Journal of International Business Studies, 23(4): 761-771.

Rugman, A. M., \& Verbeke, A. 2001. Subsidiary-specific advantages in multinational enterprises. Strategic Management Journal, 22(3): 237-250.

Rugman, A. M., \& Verbeke, A. 2003. Extending the theory of the multinational enterprise: internalization and strategic management perspectives. Journal of International Business Studies, 34(2): 125-137.

Rugman, A. M., \& Verbeke, A. 2004. A perspective on regional and global strategies of multinational enterprises. Journal of International Business Studies, 35(1): 3-18.

Rugman, A. M., Verbeke, A., \& Yuan, W. 2011. Re-conceptualizing Bartlett and Ghoshal's classification of national subsidiary roles in the multinational enterprise. Journal of Management Studies, 48(2): 253-277.

Schilke, O., \& Goerzen, A. 2010. Alliance management capability: An investigation of the construct and its measurement. Journal of Management, 36(5): 1192-1219.

Short, J. L., Toffel, M. W., \& Hugill, A. R. 2016. Monitoring global supply chains. Strategic Management Journal, 37(9): 1878-1897.

Simon, H. A. 1955. A behavioural model of rational choice. The Quarterly Journal of Economics, 69(1): 99-118.

Strange, R., \& Humphrey, J. 2019. What lies between market and hierarchy? Insights from internalization theory and global value chain theory. Journal of International Business Studies. https://doi.org/10.1057/s41267-018-0186-0.

Teece, D. 1986. Profiting from technological innovation: Implications for integration, collaboration, licensing and public policy. Research Policy, 15(6): 285-305.

Teece, D., Pisano, G., \& Shuen, A. 1997. Dynamic capabilities and strategic management. Strategic Management Journal, 18(7): 537-556.

Thaler, R. H. 2016. Behavioral economics: Past, present, and future. American Economic Review, 106(7): 1577-1600.

Tversky, A., \& Kahneman, D. 1974. Judgment under uncertainty: Heuristics and biases. Science, 185(4157): 1124-1131. 
Verbeke, A. 2013. International business strategy, 2nd Edn. Cambridge: Cambridge University Press.

Verbeke, A., \& Asmussen, C. G. 2016. Global, local, or regional? The locus of MNE strategies. Journal of Management Studies, 53(6): 1051-1075.

Verbeke, A., \& Forootan, M. Z. 2012. How good are multinationality-performance (M-P) empirical studies? Global Strategy Journal, 2(4): 332-344.

Verbeke, A., \& Greidanus, N. 2009. The end of the opportunism vs trust debate: Bounded reliability as a new envelope concept in research on MNE governance. Journal of International Business Studies, 40(9): 1471-1495.

Verbeke, A., \& Kano, L. 2015. The new internalization theory and multinational enterprises from emerging economies: $A$ business history perspective. The Business History Review, 89(3):415-445.

Wang, G., Dou, W., Zhu, W., \& Zhou, N. 2015. The effects of firm capabilities on external collaboration and performance: The moderating role of market turbulence. Journal of Business Research, 68(9): 1928-1936.

Wang, S. L., \& Li, D. 2019. Responding to public disclosure of corporate social irresponsibility in host countries: Information control and ownership control. Journal of International Business Studies. https://doi.org/10.1057/s41267-019-00224-w.

Wernerfelt, B. 1984. A resource-based view of the firm. Strategic Management Journal, 5(2): 171-180.

White, S., \& Siu-Yun Lui, S. 2005. Distinguishing costs of cooperation and control in alliances. Strategic Management Journal, 26(10): 913-932.

Williamson, O. E. 1975. Markets and hierarchies: Analysis and antitrust implications. New York, NY: Free Press.

Williamson, O. E. 1991. Comparative economic organization: The analysis of discrete structural alternatives. Administrative Science Quarterly, 36(2): 269-296.

Young, S. \& Tavares, A. T. 2004. Centralization and autonomy: Back to the future. International Business Review, 13(2): 215-237.

Zeng, R., Grøgaard, B., \& Steel, P. 2018. Complements or substitutes? A meta-analysis of the role of integration mechanisms for knowledge transfer in the MNE network. Journal of World Business, 53(4): 415-432.

Zollo, M., \& Winter, S. G. 2002. Deliberate learning and the evolution of dynamic capabilities. Organization Science, 13(3): 339-351.

\section{ABOUT THE AUTHORS}

Rajneesh Narula is the John H. Dunning Chair of International Business Regulation at the Henley
Business School, University of Reading, UK. His research and consulting have focused on the role of multinational firms in economic development, innovation and industrial policy, informality, R\&D alliances and outsourcing. He is currently an editor of Journal of International Business Studies.

Christian Geisler Asmussen is Professor of International Management at King's College London. Drawing on a background in economics, but applying an interdisciplinary approach, his research and teaching revolve around competitive advantage, globalization, and the expansion trajectories of multinational corporations.

Tailan Chi is Richard C. Notebaert Distinguished Professor of International Business \& Global Studies at the Lubar School of Business, University of Wisconsin-Milwaukee. His research uses efficiencybased theoretical approaches (institutional economics, game theory and option theory) to study interfirm and intrafirm organizational forms and their implications for the development and exploitation of intangible assets in international business. He is currently an editor of Journal of International Business Studies.

Sumit Kumar Kundu is the James K. Batten Eminent Scholar Chair in International Business in the College of Business at Florida International University. His research focuses on multinationality and performance, international entrepreneurship, emerging market multinationals, offshoring and outsourcing, entry modes, and service multinational enterprises.

Publisher's Note Springer Nature remains neutral with regard to jurisdictional claims in published maps and institutional affiliations.

Accepted by Alain Verbeke, Editor-in-Chief, 22 July 2019. This editorial has been with the authors for one revision and was single-blind reviewed. 